\title{
Physicochemical properties and physiological activities of acai berry extract fermented by lactic acid bacteria
}

\author{
Ji Wan Kim, Joo-Heon Hong* \\ Department of Food Science and Technology, Deagu Catholic University, Daegu 38430, Korea
}

유산균 발효 아사이베리 추출물의 이화학적 품질 특성 및 생리활성

\author{
김지완 - 홍주헌 ${ }^{*}$ \\ 대구가톨릭대학교 식품공학과
}

\begin{abstract}
This study was conducted to investigate the physicochemical properties and physiological activities of acai berry extract fermented by lactic acid bacteria (LAB). The acai berry extract was prepared according using fermentation times ranging from 0 to $72 \mathrm{~h}$. The viable cell count of lactic acid bacteria increased to $7.38 \mathrm{log} \mathrm{CFU} / \mathrm{mL}$ after $48 \mathrm{~h}$ fermentation, while $\mathrm{pH}$ was 4.20 , and the acidity had increased to $0.54 \%$. In addition, total sugar and total anthocyanin contents were $51.50 \mathrm{~g} / 100 \mathrm{~g}$ and $141.83 \mathrm{mg} / \mathrm{L}$ at $0 \mathrm{~h}$ fermentation, respectively; after $48 \mathrm{~h}$, total sugar content decreased to $41.86 \mathrm{~g} / 100 \mathrm{~g}$, while after 72 , total anthocyanin content increased to $182.74 \mathrm{mg} / \mathrm{L}$. Furthermore, after $48 \mathrm{~h}$, total phenolic, flavonoid, and proanthocyanidin contents increased to $34.74,25.88$, and $3.59 \mathrm{~g} / 100 \mathrm{~g}$, respectively. The DPPH and ABTS radical scavenging activities at $48 \mathrm{~h}$ were also determined, and these were found to be 81.25 and $83.46 \%$ at a concentration of $1,000 \mu \mathrm{g} / \mathrm{mL}$, respectively. Moreover, the FRAP and reducing power of the fermented acai beny extract at $48 \mathrm{~h}$ were $0.97 \mu \mathrm{M}$ and 1.10 at $1,000 \mu \mathrm{g} / \mathrm{mL}$, respectively. Additional, the protective effect against oxidative stress in L132 cells was $89.60 \%$ after $48 \mathrm{~h}$ fermentation. The obtained results therefore suggested that fermented acai berry extract has the potential for application as a functional processing material in the food industry.
\end{abstract}

Key words : acai berry extract, lactic acid bacteria, physicochemical properties, antioxidant activity, anthocyanin

\begin{abstract}
서 론
아사이베리(Euterpe oleracea Mart.)는 브라질 북부 아마 존 열대지역의 늪지나 범람원에서 자생하는 야자나무의 열매로 수세기 동안 아마존 원주민들이 질병의 치료 및 에너지 보충을 위해 애용해 왔으며, 브라질뿐만 아니라 세계적으로 소비가 증가하고 있는 식품이다(Jung, 2012). 아사이베리는 수확하고 나면 바로 상하는 특성 때문에 브라질에서 주로 소비되어 왔으나, 가공기술의 발달로 냉 동 및 동결건조 등의 형태로 수출이 되기 시작하면서 국내
\end{abstract}

수요 또한 증가하였다(Pacheco-palencia 등, 2007; Jung, 2012). 아사이베리에는 특히 페놀성 화합물, 플라보노이 드 및 안토시아닌과 같은 다양한 생리활성 물질들을 함유 하고 있는 관계로 기능성 식품 소재로 많은 각광을 받고 있다(Menezes 등, 2011).

유산균은 탄수화물 발효를 통해 최종 대사산물로 유산 을 생산하는 균이며(Kang 등, 2009), 식품의 부패를 방지 하고, bacteriocin과 같은 항균물질을 분비하여 식중독균을 억제하며, 사람의 장내 $\mathrm{pH}$ 를 낮추어 부패세균의 증식을 억제하는 등의 효과를 가지는 미생물로 알려져 있다(Park

*Corresponding author. E-mail : jhhong@cu.ac.kr, Phone : +82-53-850-3218, Fax : +82-53-850-3218

Received 11 February 2020; Revised 13 April 2020; Accepted 28 April 2020.

Copyright (c) The Korean Society of Food Preservation.

This is an Open Access article distributed under the terms of the Creative Commons Attribution Non-Commercial License (http://creativecommons.org/licenses/by-nc/4.0) which permits unrestricted non-commercial use, distribution, and reproduction in any medium, provided the original work is properly cited. 
과 Jang, 2003). 유산균은 인간이 이용할 수 있는 가장 유익 한 미생물의 한 종류로서 300-400여 종이 있는 것으로 알려져 있으며(Kim 등, 2009), 식품에 활용되는 대표적인 유산균으로는 Lactococcus, Lactobacillus, Bifidus 등이 있 으며, 구체적인 기작은 밝혀지지 않았지만 비병원성으로 안전한 균주이며, 장내에서 저해 물질의 생성 등 기능적으 로 유용함이 보고되고 있다(Ha 등, 2010). 유산균의 주요 대사물질인 lactic acid는 $\mathrm{pH}$ 의 저하를 통해 보존성을 향상 시킬 뿐만 아니라, 미생물의 생육을 억제하고, 항균작용을 나타내는 역할을 한다(Lee와 Hong, 2015). 발효 공정을 거칠 경우, 첨가물 처리가 용이하지 못하다는 단점이 발생 하지만, 미생물의 분해작용을 통해 새로운 기능성 성분의 생성, 독성의 감소, 풍미의 향상 및 저장성 향상 등 많은 장점을 가지므로 식품에 꾸준히 적용되고 있는 추세이다 (Park 등, 2006). 또한, 발효 공정을 통해 천연물의 생리활 성 효과를 상승시킬 수 있으며, 미생물과의 상호작용으로 인해 상승효과를 나타내어 생리활성 효능이 증가될 수 있다(Jeon 등, 2005; Kong 등, 2008).

현재까지는 아사이베리 추출물의 항산화 활성 및 생리 활성에 대한 선행연구는 있었으나, 대부분 추출 용매에 따른 생리활성에 관한 연구가 보고되었고(Chung, 2012), 아사이베리 첨가 와인의 이화학적 품질 특성에 관한 연구 결과가 보고되었으나(Kim, 2013) 유산균을 이용하여 발효 시킨 아사이베리 추출물의 이화학적 품질 특성 및 생리활 성에 관한 연구는 아직 미비한 실정이다.

따라서 본 연구에서는 아사이베리에 유산균을 접종하 여 발효시간별로 발효 추출물을 제조하여 이화학적 품질 특성과 생리활성을 확인하였으며, 유산균 발효 아사이베 리의 활용 가능성을 조사하였다.

\section{재료 및 방법}

\section{실험재료}

실험재료는 아사이베리 분말(Sung poong Co., Anseong, Korea)을 동결건조 상태로 구입하여 실온 보관하면서 본 실험에 사용하였다. 시료는 아사이베리 동결건조 분말 10 $\mathrm{g}$ 에 증류수 $100 \mathrm{~mL}$ 를 첨가한 다음 autoclave(HB-506-4, Hanbaek Science Co., Bucheon, Korea)를 이용하여 $121^{\circ} \mathrm{C}$ 15 분간 멸균 후 실험에 사용하였다.

\section{유산균 발효물 제조}

유산균 발효 아사이베리 추출물 제조를 위하여 사용한 균주는 한국미생물보존센터로부터 분양받은 Lactobacillus plantarum KCCM 11322 균주로, MRS broth(Difco Co., Detroit, MI, USA) 배지에 24시간 동안 전 배양한 다음, 배양액 $1 \%(\mathrm{v} / \mathrm{v})$ 를 멸균된 아사이베리 추출물에 접종하고, $30^{\circ} \mathrm{C}$ 에서 0-72시간 정치배양(IL-21, Jeio tech, Daejeon, Korea)하였다. 배양이 완료된 발효물을 동결건조(Free Zone 2.5, Labconco Co., Kansas, MO, USA)하여 10 배의 증류수 를 가한 후 $100^{\circ} \mathrm{C}$ 에서 4 시간 동안 환류냉각추출기 $(\mathrm{CA}-$ 1112, Eyela CO., Tokyo, Japan)를 이용하여 추출하였다. 추출 후 불순물을 제거하기 위해 여과지(Whatman No.4, Whatman International Ltd., Maidstone, England)를 사용하 여 여과 후 동결건조기(Free Zone 2.5, Labconco Co.)를 이용하여 건조한 다음 $-70^{\circ} \mathrm{C}$ 이하의 암소에서 보관하며, 분석용 시료로 사용하였다.

\section{생균수, $\mathrm{pH}$ 및 산도 측정}

생균수 측정은 배양액 $1 \mathrm{~mL}$ 에 멸균수 $9 \mathrm{~mL}$ 를 넣고 균질 화한 다음 10 배 희석법으로 희석하여 MRS agar(Difco Co.) 평판배지에 도말하고, $30^{\circ} \mathrm{C}$ 에서 48 시간 배양한 다음 형성 된 colony 수를 계측하고, 희석배수를 곱하여 나타내었다. $\mathrm{pH}$ 측정은 $\mathrm{pH}$ meter(CH-8603, Mettler toledo Instruments Ltd., Langacher, Switzerland)를 이용하여 배양액 $3 \mathrm{~mL}$ 를 취하여 3회 반복 측정하였다. 또한, 총산도는 $0.1 \mathrm{~N} \mathrm{NaOH}$ 를 $\mathrm{pH}$ 가 8.3이 될 때까지 적정하였으며, 적정에 소비되는 $0.1 \mathrm{~N} \mathrm{NaOH}$ 용액의 소비량을 유기산 함량으로 환산하여 표시하였다.

산도 $(\%)=[\mathrm{a} \times \mathrm{f} \times 0.009 / 10 \times$ 시료의 비중 $] \times 100$

a: $0.1 \mathrm{~N} \mathrm{NaOH}$ 의 소비량 $(\mathrm{mL})$

f: $0.1 \mathrm{~N} \mathrm{NaOH}$ 의 역가

0.009 : 유산계수 $(0.1 \mathrm{~N} \mathrm{NaOH} 1 \mathrm{~mL})$

\section{총당 함량 및 총안토시아닌 함량 분석}

총당 함량은 phenol-sulfuric acid 방법(Dubois 등, 1956) 을 응용하여 측정하였다. 시료 $1 \mathrm{~mL}$ 와 $5 \%$ phenol $1 \mathrm{~mL}$ 및 진한 $\mathrm{H}_{2} \mathrm{SO}_{4} 5 \mathrm{~mL}$ 를 혼합하여 20분간 반응시킨 후, 분광 광도계(Ultraspec 2100pro, Biochrom Ltd., Cambridge, UK) 를 이용하여 $470 \mathrm{~nm}$ 에서 흡광도를 측정하였다. 총당 함량 은 glucose(Sigma-Aldrich Co., St. Louis, MO, USA)를 사용 하여 작성한 표준곡선으로부터 계산하였다.

총안토시아닌 함량은 Lee 등(Lee 등, 2005)의 방법에 따라 시료 $0.1 \mathrm{~mL}$ 에 $\mathrm{pH} 1.0 \operatorname{buffer}(0.2 \mathrm{M}$ potassium chloride+0.2 M hydrochloric acid) 또는 $\mathrm{pH} 4.5 \operatorname{buffer}(0.2$ $\mathrm{M}$ potassium phosphate $+0.1 \mathrm{M}$ citric acid) $2 \mathrm{~mL}$ 를 각각 혼합 한 다음 분광광도계(Ultraspec 2100pro, Biochrom Ltd.)를 이용하여 $520 \mathrm{~nm}$ 와 $700 \mathrm{~nm}$ 에서 흡광도를 측정하였다. 총 안토시아닌 함량은 아래와 같이 cyanidin-3-glucoside를 기 준으로 계산하였다. 
Total anthocyanin content $(\mathrm{mg} / \mathrm{L})=$

$$
\frac{A \times M W \times D F \times 1,000}{\epsilon \times 1}
$$

$\mathrm{A}=\left(\mathrm{A}_{\lambda 520}-\mathrm{A}_{\lambda 700}\right)_{\mathrm{pH}}{ }_{1.0}-\left(\mathrm{A}_{\lambda 520}-\mathrm{A}_{\lambda 700}\right)_{\mathrm{pH}} 4.5$

$\mathrm{MW}=$ Molecular weight of cyanidin-3-glucoside

$$
=449.2 \mathrm{~g} / \mathrm{mol}
$$

$\mathrm{DF}=$ Dilution factor

$\varepsilon=$ The molar absorptivity $=26,900 \mathrm{~L} / \mathrm{cm} \cdot \mathrm{mol}$

\section{총폴리페놀 함량 및 총플라보노이드 함량 분석}

총폴리페놀 함량은 Folin-Denis법(Singleton과 Rossi, 1965) 에 따라 시료 $1 \mathrm{~mL}$ 에 $1 \mathrm{~N}$ Folin Ciocalteu reagent $1 \mathrm{~mL}$ 를 첨가하고 충분히 혼합한 다음 $20 \%$ sodium carbonate $1 \mathrm{~mL}$ 를 첨가하여 실온의 암소에서 30 분간 반응시킨 후 분광광 도계(Ultrospec 2100pro, Biochrom Ltd.)를 이용하여 725 $\mathrm{nm}$ 에서 흡광도를 측정하였다. 총폴리페놀 함량은 tannic $\operatorname{acid}($ Sigma-Aldrich Co.)를 사용하여 작성한 표준곡선으로 부터 계산하였다.

총플라보노이드 함량 측정은 Davis(Davis, 1947)의 방법 을 응용하여 측정하였다. 시료 $1 \mathrm{~mL}$ 에 $5 \%$ sodium nitrite $150 \mu \mathrm{L}$ 를 혼합하여 실온에서 6 분간 반응시킨 후 $10 \%$ aluminium chloride $300 \mu \mathrm{L}$ 를 첨가하고 실온에서 5 분간 반 응시킨 다음 $1 \mathrm{~N} \mathrm{NaOH} 1 \mathrm{~mL}$ 와 혼합한 후 분광광도계를 이용하여 $510 \mathrm{~nm}$ 에서 흡광도를 측정하였다. 총플라보노 이드 함량은 Rutin(Sigma-Aldrich Co.)을 정량하여 작성한 표준곡선으로부터 계산하였다.

\section{총프로안토시아니딘 함량 분석}

총프로안토시아니딘 함량은 vanillin-sulfuric acid법을 변형하여 측정하였다(Takahama 등, 2010). 시료 $0.2 \mathrm{~mL}$ 에 $1.2 \%$ vanillin 용액 $0.5 \mathrm{~mL}$ 와 $20 \% \mathrm{H}_{2} \mathrm{SO}_{4} 0.5 \mathrm{~mL}$ 를 첨가하 여 20 분간 방치 후 $500 \mathrm{~nm}$ 에서 흡광도를 측정하였다. 총프 로안토시아니딘 함량은 (+)-catechin(Sigma-Aldrich Co.)을 사용하여 작성한 표준곡선으로부터 계산하였다.

\section{DPPH radical 소거활성 측정}

DPPH radical 소거활성은 1,1-diphenyl-2-pycrylhydrazyl $(\mathrm{DPPH})$ 의 환원력을 이용하여 측정하였다(Blois, 1958). 즉, DPPH reagent는 DPPH(Sigma-Aldrich Co.) $12 \mathrm{mg}$ 을 99.9\% ethanol $100 \mathrm{~mL}$ 에 용해한 후 증류수 $100 \mathrm{~mL}$ 를 첨가하여 흡광도를 $517 \mathrm{~nm}$ 에서 약 1.5 로 조정하여 제조하였다. 시료 $0.5 \mathrm{~mL}$ 에 DPPH reagent $5 \mathrm{~mL}$ 를 혼합하여 실온에서 15 분간 반응시킨 후 분광광도계(Ultrospec 2100pro, Biochrom Ltd.) 로 흡광도를 측정하고 아래와 같이 계산하였다.
DPPH radical scavenging activity $(\%)=1-\frac{\mathrm{S}}{\mathrm{C}} \times 100$

S: Absorbance of sample at $517 \mathrm{~nm}$

C: Absorbance of control at $517 \mathrm{~nm}$

\section{ABTS radical 소거활성 측정}

시료의 2,2'-Azino-bis(3-ethylbenzothiazoline-6-sulfonic acid) (ABTS) radical 소거활성은 양이온(ABTS ${ }^{+}$에 대한 항산화 물질의 소거능을 이용하여 측정하였다(Re 등, 1999). ABTS reaction 혼합물은 $7.4 \mathrm{mM} \mathrm{ABTS(Sigma-Aldrich} \mathrm{Co.)와} 2.6$ $\mathrm{mM}$ potassium persulfate를 최종 농도로 혼합하여 실온인 암소에서 24시간 동안 방치하여 $\mathrm{ABTS}^{+}$을 형성시킨 후 $732 \mathrm{~nm}$ 에서 흡광도 값이 $0.70 \pm 0.03$ 이 되게 증류수를 사용 하여 희석하였다. 시료 $50 \mu \mathrm{L}$ 에 ABTS reaction 혼합물 950 $\mu \mathrm{L}$ 를 첨가하여 혼합 후 실온에서 10 분간 반응시킨 다음 분광광도계(Ultraspec 2100pro, Biochrom Ltd.)를 이용하여 $732 \mathrm{~nm}$ 에서 흡광도를 측정하였다. ABTS radical 소거활성 은 시료의 첨가 전과 후의 차이를 아래와 같이 백분율로 나타내었다.

ABTS radical scavenging activity $(\%)=1-\frac{\mathrm{S}}{\mathrm{C}} \times 100$

S: Absorbance of sample at $732 \mathrm{~nm}$

C: Absorbance of control at $732 \mathrm{~nm}$

Ferric reducing antioxidant power(FRAP) 측정

FRAP는 Benzie와 Strain의 방법(Benzie과 Strain, 1996) 에 따라 다음과 같이 측정하였다. FRAP reagent는 $25 \mathrm{~mL}$ acetate buffer(300 mM, pH 3.6)를 $40 \mathrm{mM} \mathrm{HCl}$ 에 용해한 $10 \mathrm{mM}$ 2,4,6-tris(2-pyridyl)-s-triazine(TPTZ, Sigma-Aldrich Co.) $2.5 \mathrm{~mL}$ 와 $20 \mathrm{mM}$ ferric chloride $\left(\mathrm{FeCl}_{3} \cdot 6 \mathrm{H}_{2} \mathrm{O}\right) 2.5 \mathrm{~mL}$ 를 첨가하여 제조하였으며, 실험 직전 $37^{\circ} \mathrm{C}$ 에서 10 분 이상 반응시켜 사용하였다. 시료 $25 \mu \mathrm{L}$ 에 제조된 FRAP reagent $175 \mu \mathrm{L}$ 를 넣고 $37^{\circ} \mathrm{C}$ 암소에서 30 분간 반응시킨 후 분광광 도계(Ultraspec 2100pro, Biochrom Ltd.)를 이용하여 $590 \mathrm{~nm}$ 에서 흡광도를 측정하였다. $\mathrm{FRAP}$ 는 $\mathrm{FeSO}_{4} \cdot 7 \mathrm{H}_{2} \mathrm{O}$ (SigmaAldrich Co.)을 정량하여 작성한 표준곡선으로부터 계산 하였다.

\section{환원력 측정}

환원력 측정은 Oyaizu(Oyaizu, 1986)의 방법에 따라 활 성산소종 및 유리기에 전자를 공여하는 능력을 이용하여 다음과 같이 측정하였다. 시료 $1 \mathrm{~mL}$ 에 $0.2 \mathrm{M}$ phosphate $\operatorname{buffer}(\mathrm{pH}$ 6.6) $2.5 \mathrm{~mL}$ 와 $1 \%$ potassium ferricyanide 용액 $2.5 \mathrm{~mL}$ 를 가한 후 $50^{\circ} \mathrm{C}$ 에서 30 분간 반응시켰다. 반응 후 $10 \%$ trichloroacetic acid 용액 $2.5 \mathrm{~mL}$ 를 가한 후 원심분리한 
뒤, 상등액 $2.5 \mathrm{~mL}$ 에 증류수 $2.5 \mathrm{~mL}$ 와 $0.1 \% \mathrm{FeCl}_{3}$ 용액 $0.5 \mathrm{~mL}$ 를 혼합한 다음 분광광도계(Ultraspec 2100pro, Biochrom Ltd.)를 이용하여 $700 \mathrm{~nm}$ 에서 흡광도를 측정하 였다.

\section{세포주 배양}

인간 폐상피 세포주인 L132(KCLB No. 10005)는 한국세 포주은행(KTCC, Seoul, Korea)에서 분양받아 실험에 사용 하였다. 세포배양은 DMEM 배지(Welgene, Daegu, Korea) 를 이용하여 각각 $10 \%$ fetal bovine serum(Gibco BRL Co., Grand Island, NY, USA), 2\% penicillin-streptomycin(Gibco $\mathrm{BRL}$ Co.)을 첨가하여 $37^{\circ} \mathrm{C}, 5 \% \mathrm{CO}_{2}$ incubator(MCO-18AIC, Sanyo Co., Osaka, Japan)에서 배양하였다.

\section{세포독성 시험}

유산균 발효 아사이베리 추출물의 L132 세포의 세포독성은 3-(4,5-dimethylthiazol-2-yl)-2,5-diphenyltetrazolium bromide (MTT, Sigma-Aldrich Co.) 시약의 환원 정도를 측정하는 MTT assay 방법(Van 등, 2011)을 사용하여 측정하였다. 배양된 세포주를 $1 \times 10^{4} \mathrm{cell} / \mathrm{mL}$ 로 96-well plate에 첨가하 여 24시간 배양하고, $100-1,000 \mu \mathrm{g} / \mathrm{mL}$ 농도로 제조한 시료를 처리한 후 12 시간 동안 배양하였다. 배양 후 PBS 완충용액에 녹인 MTT 용액 $(5 \mathrm{mg} / \mathrm{mL})$ 을 각 well에 $10 \mu \mathrm{L}$ 씩 첨가하고, 다시 4시간 동안 배양하여 MTT가 환원되도 록 하였다. 배양 종료 후 생성된 formazan 결정이 흐트러 지지 않게 상등액을 완전히 제거한 다음 각각의 well에 $100 \mu \mathrm{L}$ 씩 dimethyl sulfoxide(DMSO, Junsei Chemical Co., Tokyo, Japan)를 첨가하고, 실온에서 10 분간 반응시켜 formazan 결정을 완전히 용해한 다음 microplate reader (UVM-340, Asys Co., Biochrom)를 이용하여 $540 \mathrm{~nm}$ 에서 흡광도를 측정하였다. 세포 생존율은 시료를 처리하지 않은 세포를 대조군으로 하여 상대적인 백분율로 나타내 었다.

\section{산화적 손상에 대한 세포보호 효과 시험}

유산균 발효 아사이베리 추출물의 L132 세포에 대한 보호 효과는 과산화수소에 의해 유도된 산화적 세포 사멸 에 대한 보호 효과를 확인하기 위해 Hwang(2003)의 방법 에 따라 다음과 같이 측정하였다. 배양된 세포주를 $1 \times 10^{4}$ $\mathrm{cell} / \mathrm{mL}$ 로 96-well plate에 첨가하여 24시간 배양하고, 세포 내에 활성산소를 형성시키기 위해 $1.0 \mathrm{mM} \mathrm{H}_{2} \mathrm{O}_{2}$ 와 100 $1,000 \mu \mathrm{g} / \mathrm{mL}$ 농도로 제조한 시료를 처리한 후 12시간 동안 배양하였다. 배양 후 PBS 완충용액에 녹인 MTT 용액(5 $\mathrm{mg} / \mathrm{mL}$ )을 각 well에 $10 \mu \mathrm{L}$ 씩 첨가하고, 다시 4시간 동안 배양하여 MTT가 환원되도록 하였다. 배양 종료 후 생성된 formazan 결정이 흐트러지지 않게 상등액을 완전히 제거 한 다음, 각각의 well에 $100 \mu \mathrm{L}$ 씩 $\mathrm{DMSO}$ 를 첨가하고 실온 에서 10 분간 반응시켜 formazan 결정을 완전히 용해한 후 microplate reader(UVM-340, ASYS Co.)를 이용하여 540 $\mathrm{nm}$ 에서 흡광도를 측정하였다. 세포 생존율은 시료를 처리 하지 않은 세포를 대조군으로 하여 상대적인 백분율로 나타내었다.

\section{통계처리}

모든 실험은 3회 반복 수행하여 평균표준편차로 나타 내었고 SPSS(19.0, SPSS Inc., Chicago, Il, USA)를 이용하 여 각 시료 분석결과에 대한 유의성 검정은 분산 분석 후 $\mathrm{p}<0.05$ 수준에서 Ducan's multiple range test를 실시하였 다. 유산균 발효 아사이베리 추출물의 배양시간에 따른 세포실험에 대한 유의성은 Student's t-test를 통하여 검정 하였다.

\section{결과 및 고찰}

\section{생균수, $\mathrm{pH}$ 및 산도}

유산균 발효 아사이베리 추출물의 발효시간에 따른 변 화를 확인하기 위하여 생균수, $\mathrm{pH}$ 및 산도를 Table 1에

Table 1. Viable cell count, $\mathrm{pH}$ and total acidity of acai berry extract according to fermentation time $(0$ - 72 h)

\begin{tabular}{cccc}
\hline Fermentation time $(\mathrm{h})$ & Viable cell count $(\log \mathrm{CFU} / \mathrm{mL})$ & $\mathrm{pH}$ & Total acidity $(\%)$ \\
\hline 0 & $6.51 \pm 0.00^{\mathrm{fl})}$ & $4.44 \pm 0.02^{\mathrm{a}}$ & $0.24 \pm 0.01^{\mathrm{f}}$ \\
6 & $7.19 \pm 0.01^{\mathrm{d}}$ & $4.30 \pm 0.02^{\mathrm{c}}$ & $0.29 \pm 0.01^{\mathrm{e}}$ \\
12 & $7.22 \pm 0.00^{\mathrm{c}}$ & $4.27 \pm 0.02^{\mathrm{d}}$ & $0.32 \pm 0.00^{\mathrm{d}}$ \\
24 & $7.35 \pm 0.01^{\mathrm{b}}$ & $4.23 \pm 0.03^{\mathrm{d}}$ & $0.36 \pm 0.00^{\mathrm{c}}$ \\
48 & $7.38 \pm 0.01^{\mathrm{a}}$ & $4.20 \pm 0.01^{\mathrm{b}}$ & $0.54 \pm 0.00^{\mathrm{a}}$ \\
72 & $6.96 \pm 0.01^{\mathrm{e}}$ & $4.29 \pm 0.01^{\mathrm{bc}}$ & $0.41 \pm 0.00^{\mathrm{b}}$ \\
\hline
\end{tabular}

${ }^{1)}$ Mean \pm SD $(n=3)$ within each column $\left({ }^{a-f}\right)$ followed by the different letter are significantly different $(p<0.05)$. 
나타내었다. 유산균 발효 아사이베리 추출물의 초기 유산 균 수는 $6.51 \log \mathrm{CFU} / \mathrm{mL}$ 로 배양시간이 증가할수록 균 수가 증가하여 48시간 배양 시 $7.38 \log \mathrm{CFU} / \mathrm{mL}$ 로 최대값 을 나타내었고, 72시간 배양 시 $6.96 \log \mathrm{CFU} / \mathrm{mL}$ 로 감소하 는 경향을 나타내었다. 이는 자작나무 수액의 유산발효 시 저장성 및 기호성 증진 연구(Kim 등, 2009)에서 48시간 발효 시 생균수가 최대값을 나타냈으며, 그 이후 점차 감 소하는 경향을 나타내었다고 보고하였는데, 본 연구결과 와 유사한 경향이었다. $\mathrm{pH}$ 의 경우, 0 시간 배양 시 $\mathrm{pH} 4.44$ 를 나타낸 후 배양시간이 증가할수록 값이 감소하였으며, 48시간 배양 시 $\mathrm{pH} 4.20$ 이었고, 72 시간에서 4.29로 다소 증가하는 경향을 나타내었다. 산도는 0 시간 배양 시 $0.24 \%$ 로 점차 증가하다 48 시간 배양 시 $0.54 \%$ 로 최대값을 나타 낸 후 72 시간 배양 시에는 $0.41 \%$ 로 감소하는 경향을 나타 내었다. $\mathrm{pH}$ 의 감소 및 산도의 증가는 유산균 배양에 의해 생성된 유기산과 미생물의 유기물 분해 시 발생하는 적은 양의 옥살산, 젖산 및 아세트산 등이 생성되어(Kim과 Bae, 1999) 잡균의 생육을 저해시킬 뿐만 아니라, 잡균에 의한 오염 방지 및 추출물의 저장성이 향상될 것으로 기대된다.

\section{이화학적 품질 특성}

발효 미생물을 통해 2차 대사산물이 생성되면서, 기존 에 존재하지 않았던 유용 생리활성 물질의 생성이 가능할 것으로 기대되어(Ha 등, 2010) 발효물을 동결건조 후 열수 추출하여 이화학적 품질 특성을 분석하였다. 유산균 발효 아사이베리 추출물의 배양시간에 따른 총당, 총폴리페놀, 총플라보노이드, 총안토시아닌 및 총프로안토시아니딘 함량은 Table 2와 같다. 총당 함량은 0 시간 배양 시 51.50 $\mathrm{g} / 100 \mathrm{~g}$ 으로 최대값을 나타내었으며, 배양 시간이 증가할 수록 감소하여 48시간 배양 시 $41.86 \mathrm{~g} / 100 \mathrm{~g}$ 으로 최소값을 나타내었다. Lim 등(2019)의 홍화 추출물에 대한 유산발 효에서 배양 기간이 증가할수록 총당 함량이 감소하는
경향이 나타났다고 보고하여 본 연구와 유사한 경향을 나타냈으며, 이는 발효 중 당분이 미생물의 주요 영양원으 로 사용되었을 것으로 사료된다(Kim 등, 2018). 또한, Schauss 등(2006)은 동결건조 아사이베리의 생리활성 및 영양성분 분석 연구에서 총탄수화물의 함량이 $52.2 \%$ 로 보고하여 본 연구결과와 유사하였으나, Chung (2012)의 연구에서는 아사이베리의 일반성분 분석 결과, 총탄수화 물의 함량이 $29.97 \%$ 였다고 보고하였는데, 이는 아사이베 리의 품종, 재배 시기, 건조 방법 등의 차이에서 기인하는 것으로 사료된다.

유산균 발효 아사이베리 추출물의 총안토시아닌 함량 은 0시간 배양 시 $141.83 \mathrm{mg} / \mathrm{L}$ 로 배양시간이 증가할수록 값이 증가하는 경향을 나타내어 72 시간 배양에서 182.74 $\mathrm{mg} / \mathrm{L}$ 로 가장 높게 나타났다. 이는 Lee와 Hong(2015)의 연 구에서 블루베리 유산발효 시 배양시간이 증가할수록 총 안토시아닌 함량이 증가하는 것과 유사한 경향을 나타내 었다. 아사이베리에 함유되어있는 안토시아닌은 플라보 노이드의 일종으로 안토시아니딘과 당의 결합체로서 구 성이 되어지며, 당고리에 방향족 또는 비 방향족 유기산이 결합되어 있는 형태로 존재한다(Michael 등, 2011).

폴리페놀 화합물은 식물계에 널리 분포되어있는 2 차 대사산물의 하나로 한 분자 내에 2개 이상의 phenolic hydroxyl기를 가지고 있기 때문에 단백질 등의 거대 분자 들과 결합하는 성질을 가지며, 항산화 효과 등의 생리활성 기능을 가지고 있다고 알려져 있다(Lee 등, 2008). 본 연구 에서 0 시간 배양의 경우, 총폴리페놀 및 총플라보노이드 함량이 각각 $32.09 \mathrm{~g} / 100 \mathrm{~g}$ 및 $20.73 \mathrm{~g} / 100 \mathrm{~g}$ 으로 나타났으 며, 배양 시간이 증가할수록 증가하는 경향을 나타내어 48시간 배양의 경우 각각 $34.74 \mathrm{~g} / 100 \mathrm{~g}$ 및 $25.88 \mathrm{~g} / 100$ $\mathrm{g}$ 을 나타내었다. $\mathrm{Ha}$ 등(2010)의 연구에서 유산발효 시의 매자나무 수피부의 총폴리페놀 및 총플라보노이드의 함 량이 비 발효물에 비해 30-40\% 및 50-70\% 증가하였다

Table 2. The contents of total sugar, anthocyanin, phenolic, flavonoid and proanthocyanidin in acai berry extract according to fermentation time $(0-72$ h)

\begin{tabular}{cccccc}
\hline $\begin{array}{c}\text { Fermentation time } \\
(\mathrm{h})\end{array}$ & $\begin{array}{c}\text { Total sugar } \\
(\text { glucose g/100 } \mathrm{g})\end{array}$ & $\begin{array}{c}\text { Total anthocyanin } \\
(\mathrm{mg} / \mathrm{L})\end{array}$ & $\begin{array}{c}\text { Total phenolic } \\
(\text { tannic acid g/100 g) }\end{array}$ & $\begin{array}{c}\text { Total flavonoid } \\
(\text { rutin g/100 g) }\end{array}$ & $\begin{array}{c}\text { Total proanthocyanidin } \\
(\mathrm{catechin} \mathrm{g} / 100 \mathrm{~g})\end{array}$ \\
\hline 0 & $51.50 \pm 1.84^{\mathrm{al})}$ & $141.83 \pm 5.49^{\mathrm{d}}$ & $32.09 \pm 0.45^{\mathrm{d}}$ & $20.73 \pm 1.03^{\mathrm{bc}}$ & $1.49 \pm 0.20^{\mathrm{d}}$ \\
6 & $49.81 \pm 2.24^{\mathrm{a}}$ & $143.72 \pm 3.35^{\mathrm{d}}$ & $33.15 \pm 0.73^{\mathrm{c}}$ & $20.88 \pm 0.90^{\mathrm{c}}$ & $2.93 \pm 0.13^{\mathrm{c}}$ \\
12 & $44.90 \pm 1.21^{\mathrm{b}}$ & $153.91 \pm 3.19^{\mathrm{c}}$ & $33.43 \pm 0.54^{\mathrm{bc}}$ & $21.95 \pm 1.54^{\mathrm{c}}$ & $3.21 \pm 0.14^{\mathrm{bc}}$ \\
24 & $42.94 \pm 1.74^{\mathrm{b}}$ & $167.38 \pm 1.62^{\mathrm{b}}$ & $34.09 \pm 0.45^{\mathrm{abc}}$ & $23.90 \pm 1.37^{\mathrm{ab}}$ & $3.42 \pm 0.10^{\mathrm{ab}}$ \\
48 & $41.86 \pm 1.46^{\mathrm{b}}$ & $181.35 \pm 3.19^{\mathrm{a}}$ & $34.74 \pm 0.37^{\mathrm{a}}$ & $25.88 \pm 1.79^{\mathrm{a}}$ & $3.59 \pm 0.32^{\mathrm{a}}$ \\
72 & $42.10 \pm 1.36^{\mathrm{b}}$ & $182.74 \pm 4.87^{\mathrm{a}}$ & $34.16 \pm 0.47^{\mathrm{ab}}$ & $25.61 \pm 1.53^{\mathrm{a}}$ & $2.99 \pm 0.08^{\mathrm{c}}$ \\
\hline
\end{tabular}

${ }^{1)}$ Mean \pm SD ( $=3$ ) within each column $\left({ }^{a-d}\right)$ followed by the different letter are significantly different $(\mathrm{p}<0.05)$. 
는 연구 결과가 나타났으며, 본 연구에서도 비 발효물에 비해 발효물의 폴리페놀 및 플라보노이드 함량이 증가한 결과를 나타내었다. 또한 Chung(2012)의 연구에서 아사이 베리 열수 추출물의 총폴리페놀 및 플라보노이드 함량을 측정한 결과, $10.54 \mathrm{mg} / 100 \mathrm{~g}$ 및 $1.88 \mathrm{mg} / 100 \mathrm{~g}$ 으로 보고된 바 있으며, 이는 추출물에 대한 결과로 본 연구의 유산균 발효 아사이베리 추출물 동결건조분말에 대한 총폴리페 놀 및 총플라보노이드 함량에 비해 낮은 값을 나타낸 것으 로 확인되었다.

프로안토시아니딘은 안토시아니딘의 폴리페놀성 물질 로 플라보노이드 생합성 경로를 통해 합성되는 식물의 이차 대사산물로 많은 종류의 식물에 존재하며, 항산화 활성이 높아 항균, 항바이러스, 항암, 항염증, 항알러지 및 혈관 확장능 등의 기능성도 보고되었다(Song과 $\mathrm{Oh}$, 1996; Fine, 2000). 총프로안토시아니딘의 함량은 0시간 배양 시 $1.49 \mathrm{~g} / 100 \mathrm{~g}$ 으로 최소값을 나타냈으며, 배양 시간
이 증가할수록 함량이 증가하는 경향을 나타내어 48 시간 배양 시 $3.59 \mathrm{~g} / 100 \mathrm{~g}$ 으로 가장 높게 분석되었다. 이는 Kennedy와 Cerpa-calderon(2008)의 적포도주 발효 동안의 프로안토시아니딘 함량의 측정 결과, 발효 기간이 증가할 수록 함량이 증가하는 경향이 나타났다고 보고된 연구 결과와 유사하였다.

\section{항산화 활성}

유산균 발효 아사이베리 추출물의 DPPH 및 $\mathrm{ABTS}$ radical 소거활성은 Fig. 1 에 나타내었다. $100-1,000 \mu \mathrm{g} / \mathrm{mL}$ 농도에서 측정하였으며, 추출물의 농도가 증가함에 따라 항산화 활성이 유의적으로 증가하는 경향을 나타내었다. $\mathrm{DPPH}$ 및 $\mathrm{ABTS}$ radical 소거활성은 식품의 항산화 활성 측정에 널리 사용되고 있으며, DPPH radical 소거활성은 음이온 라디칼을 생성하며, ABTS radical 소거활성은 양이 온 라디칼을 생성하는 차이가 있다(Kwak과 Choi, 2015).

(A)

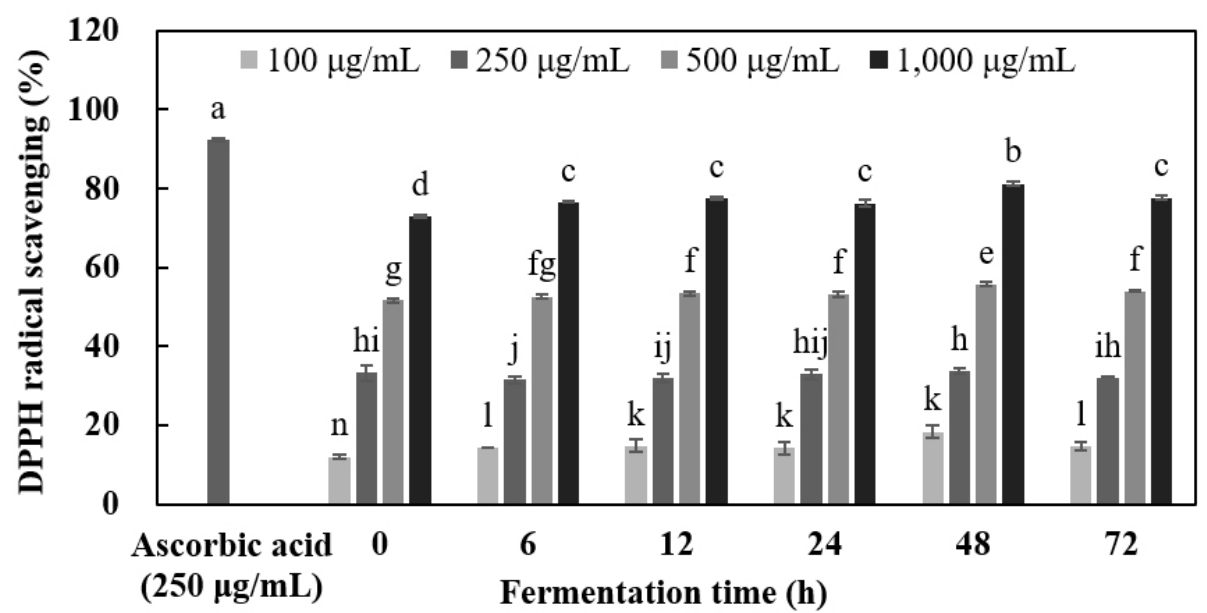

(B)

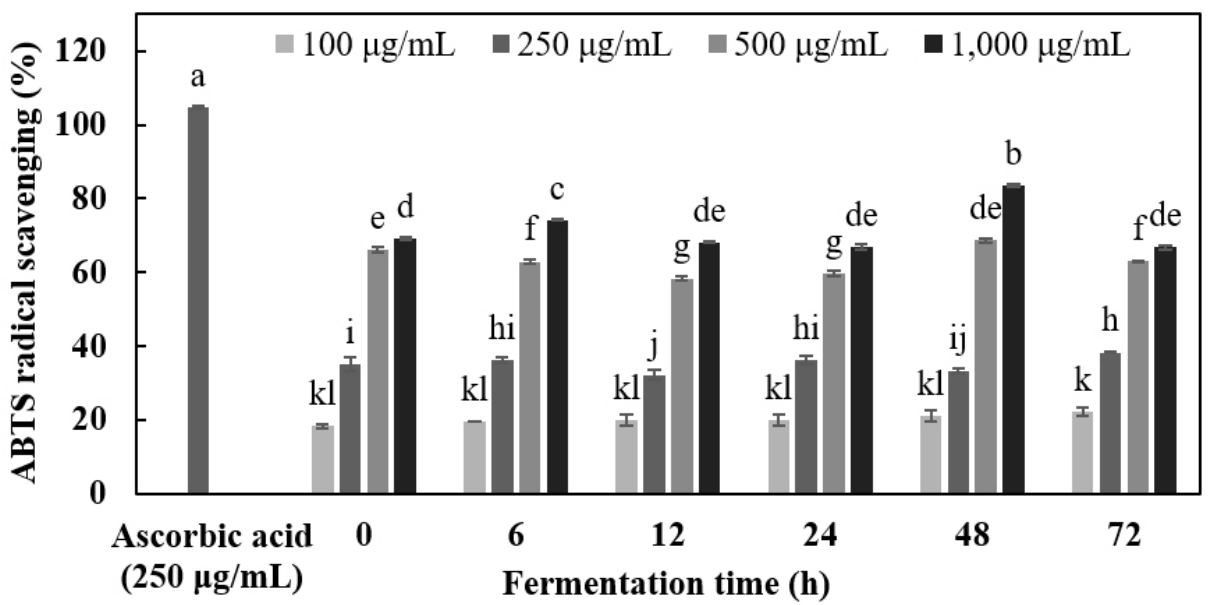

Fig. 1. DPPH radical scavenging activity (A) and ABTS radical scavenging activity (B) of acai berry extract according to fermentation time $(0$ - 72 h).

Mean \pm SD $(n=3)$ in each column $\left({ }^{a-m}\right)$ followed by the different letter are significantly differ $(\mathrm{p}<0.05)$. 
따라서 기질과 반응물질의 결합 정도가 달라 상이한 결과 나 나올 수 있다고 알려져 있다(Lee SM 등, 2012). DPPH 및 ABTS radical 소거활성은 $1,000 \mu \mathrm{g} / \mathrm{mL}$ 농도에서 0시간 배양의 경우 각각 $72.82 \%$ 및 $69.31 \%$ 의 소거활성을 나타내 었으며, 48 시간 배양 시 $81.25 \%$ 및 $83.46 \%$ 로 최대값을 나타낸 후 감소하는 경향을 나타내었으며, 이는 본 연구에 서의 총폴리페놀 및 총플라보노이드 함량 측정 결과와 유사한 경향임을 확인하였다. Chung(2012)의 연구에서 아 사이베리 열수 추출물의 DPPH radical 소거활성을 측정한 결과, $1,000 \mu \mathrm{g} / \mathrm{mL}$ 농도에서 약 $45 \%$ 의 활성을 나타내어 본 연구 결ㄴㄱㄱㅇㅔ 비해 낮은 결과값이 나타난 것을 확인할 수 있었으며, Jin 등(2016)의 연구에서 아사이베리 $70 \%$ ethanol 추출물의 ABTS radical 소거활성을 측정한 결과, $600 \mu \mathrm{g} / \mathrm{mL}$ 농도에서 $79.20 \%$ 의 항산화 활성을 나타낸다고 보고하였다.
유산균 발효 아사이베리 추출물의 FRAP 및 환원력 측 정은 Fig. 2에 나타내었다. $100-1,000 \mu \mathrm{g} / \mathrm{mL}$ 농도에서 측 정하였으며, 농도가 증가함에 따라 활성이 유의적으로 증 가하는 경향을 나타내었다. FRAP 측정 결과, $1,000 \mu \mathrm{g} / \mathrm{mL}$ 에서 0 시간 배양 시 $0.86 \mu \mathrm{M}$ 을 나타냈으며, 48 시간 배양 시 $0.97 \mu \mathrm{M}$ 로 증가하였다. 이는 앞서 $\mathrm{DPPH}$ 및 $\mathrm{ABTS}$ radical 소거활성 측정 결과, 무 발효 아사이베리 추출물에 비해 유산균 발효를 통한 아사이베리 추출물의 항산화 효능이 증가된 것과 유사한 경향이 나타났다. 환원력의 흡광도 측정 결과, $1,000 \mu \mathrm{g} / \mathrm{mL}$ 에서 0 시간 발효 시 0.98 에서 값이 점차 증가하여 48시간 배양 시 1.10 으로 최대값을 나타내 었다. 높은 환원력을 가지는 물질은 흡광도 수치가 높게 나타나며, Lactobacillus sp. 균주를 이용한 오미자 당침액 의 환원력 측정 결과, 발효 전 · 후의 결과를 비교하였을 때 발효 후의 환원력이 증가하였다고 보고된 결과(Park,

(A)

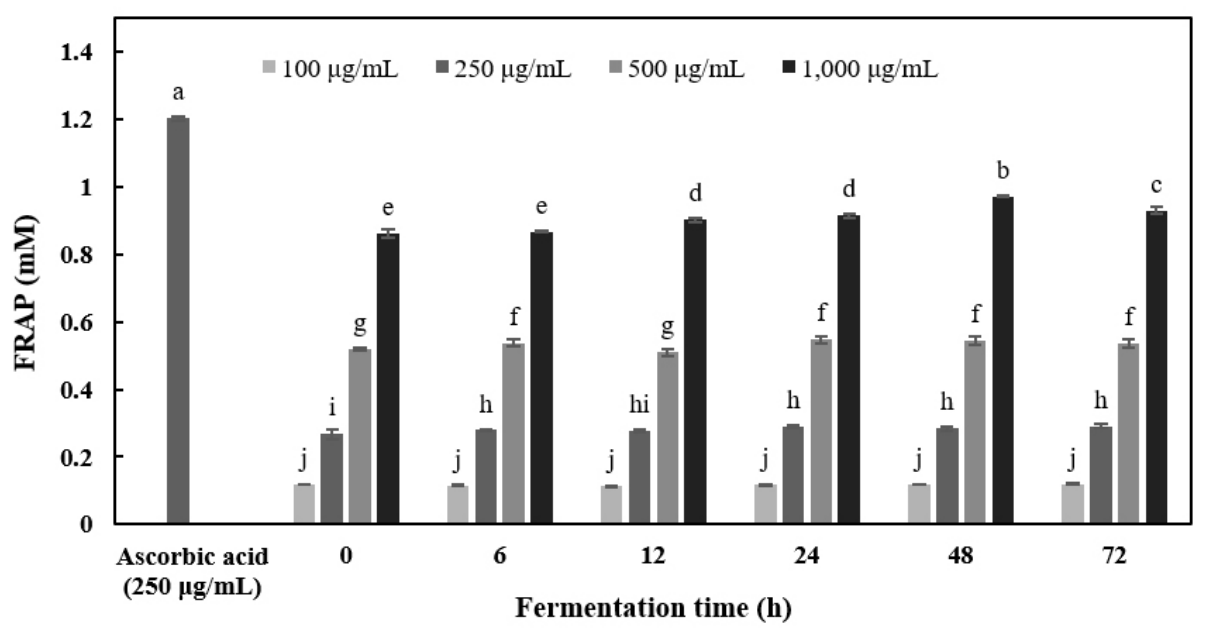

(B)

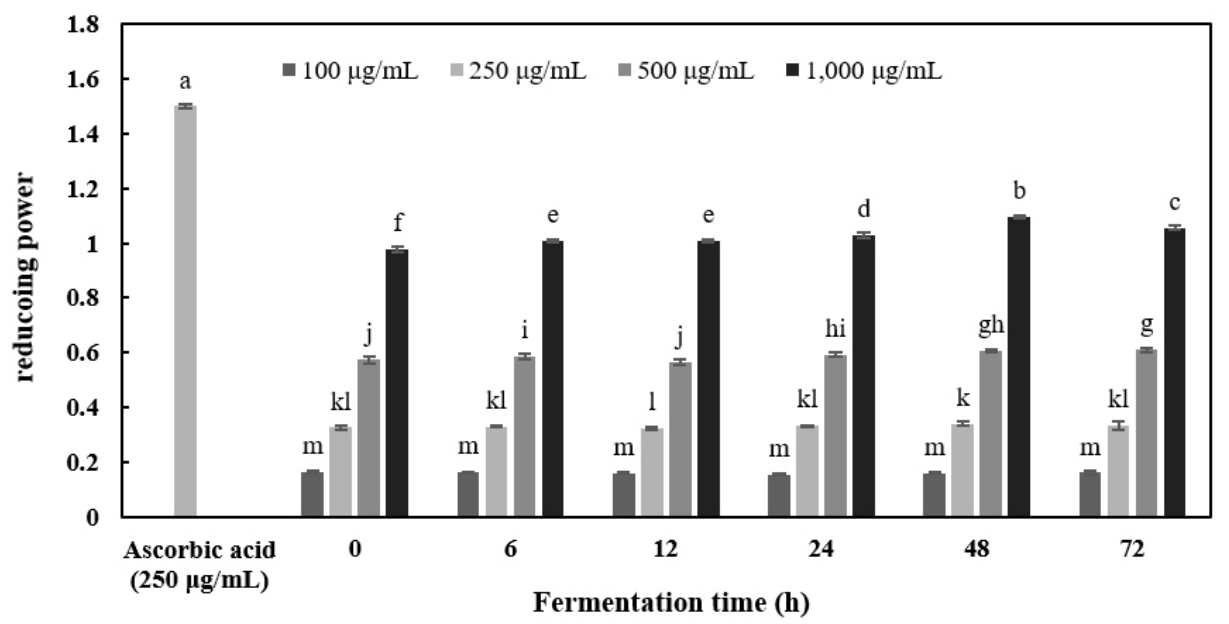

Fig. 2. Ferric reducing antioxidant power (FRAP) activity (A) and reducing power (B) of acai berry extract according to fermentation time $(0-72$ h).

Mean \pm SD $(n=3)$ in each column $\left({ }^{a-k}\right)$ followed by the different letter are significantly differerent $(\mathrm{p}<0.05)$. 
2014)와 유사한 경향을 보여주었다.

\section{산화적 손상에 대한 세포보호 효과}

유산균 발효 아사이베리 추출물을 인간 폐상피세포주 인 L132에 농도별로 처리하여 탈수소 효소작용에 의하여 수용성 기질인 MTT tetrazolium을 청자색을 띠는 비수용 성의 MTT formazan으로 환원시키는 미토콘드리아의 능 력을 이용하는 검사법인 MTT assay 방법으로 측정하였다. 세포독성 및 L132 산화적 손상에 대한 세포보호 효과는 Fig. 3과 같다. L132 세포독성은 유산균 발효 아사이베리 추출물을 $100-1,000 \mu \mathrm{g} / \mathrm{mL}$ 농도로 처리하였으며, 세포
생존율은 모든 농도에서 $\mathrm{L} 132$ 세포에 대한 독성이 나타나 지 않았으므로 $100-1,000 \mu \mathrm{g} / \mathrm{mL}$ 농도로 세포보호 효과를 확인하였다. 세포보호 효과는 $1.0 \mathrm{mM} \mathrm{H}_{2} \mathrm{O}_{2}$ 첨가구에서 $62.63 \%$ 를 나타냈으며, 이와 비교하여 모든 시료에서 활성 이 유의적으로 증가하는 것을 확인하였다. 세포보호 효과 측정 결과, 모든 시료에서 $63.64-89.60 \%$ 로 나타났으며, 농도 의존적으로 세포의 활성이 증가하는 것을 관찰할 수 있었다. 48 시간 배양 시 $1,000 \mu \mathrm{g} / \mathrm{mL}$ 농도에서 세포보 호 효과가 $89.60 \%$ 로 최대값을 나타냈으며, 총폴리페놀 함 량, 총플라보노이드 함량 및 항산화 측정 결과와 유사한 경향을 나타내었다. 이는 유산균 발효 아사이베리 추출물

(A)

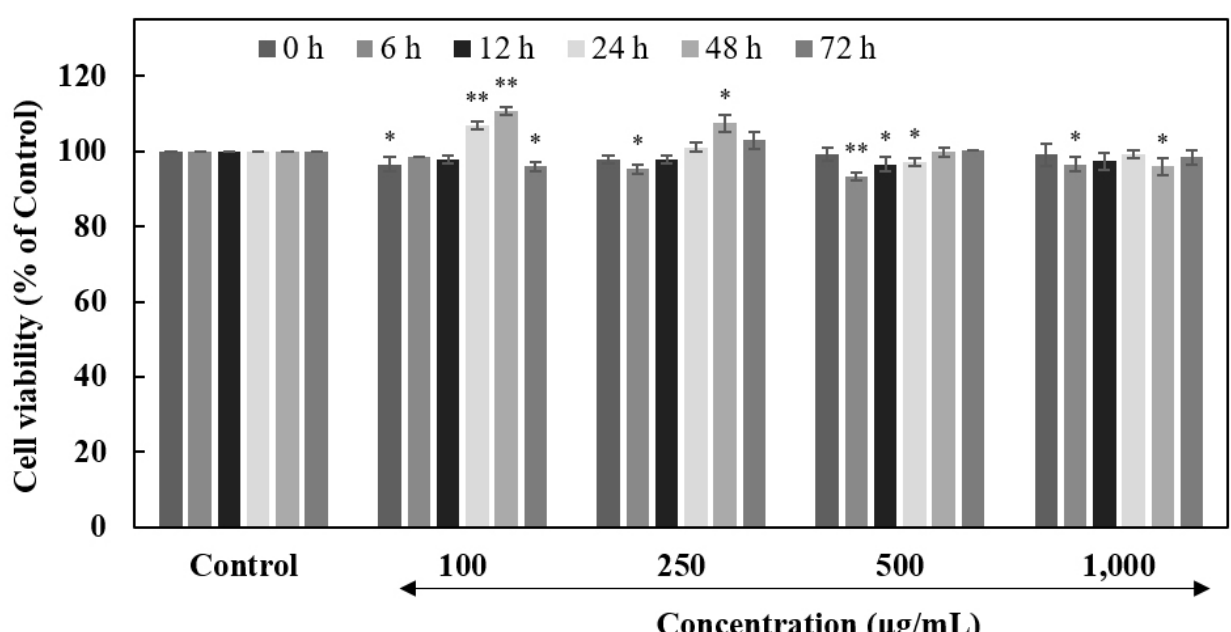

(B)

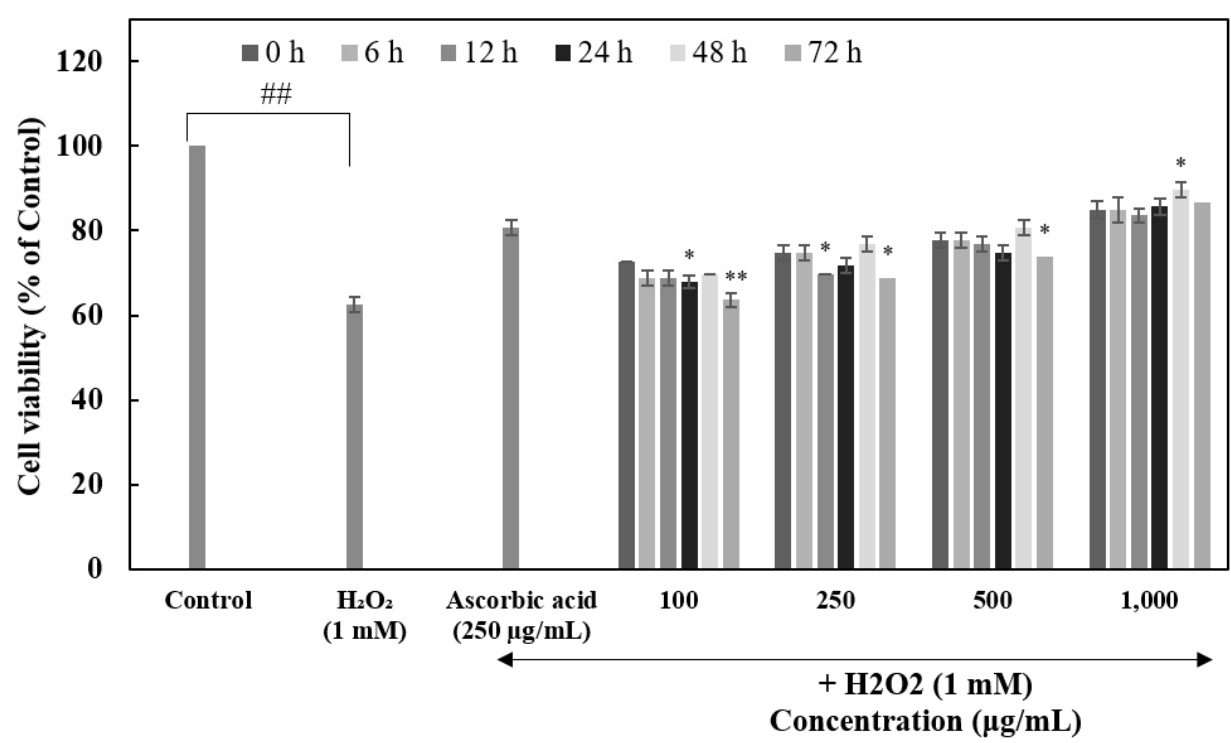

Fig. 3. MTT assay (A) and protective effects on cell viability against $\mathrm{H}_{2} \mathrm{O}_{2}(1 \mathrm{mM})$ induced oxidative damage (B) in L132 cell line of acai berry extract according to fermentation time $(0-72 \mathrm{~h})$.

(A) values are compared with the control and (B) values are compared with $0 \mathrm{~h}$ fermentation time, followed by Student's t-test. All values are expressed as the mean $\pm S D(n=3) .{ }^{\#}(p<0.05),{ }^{\# \#}(p<0.01),{ }^{*}(p<0.05)$ and ${ }^{* *}(p<0.01)$. 
의 폴리페놀 성분과 항산화 성분이 세포 내 산화적 스트레 스에서 보호 효과를 보인 것으로 사료된다(Jo 등, 2014). Kim 등(2013)의 미나리 발효액과 이를 이용한 식초의 특 성 분석과 관련된 연구 결과, 미나리 발효액의 $1,000 \mu \mathrm{g} / \mathrm{mL}$ 농도에서 $45.31 \%$ 의 세포보호 효과를 보인 것과 비교하였 을 때 유산균 발효 아사이베리 추출물의 세포보호 효과가 높은 결과를 나타내는 것을 관찰할 수 있었다. Sung 등 (2016)의 연구에서 발효 울금의 간세포 보호 효과 측정 연구 결과, 발효 울금 추출물 중 냉수 추출물 처리군에서 $86.1 \%$ 로 가장 높은 세포 생존율을 나타내었으며, 이는 비 발효 추출물 및 유기용매 추출물보다 높은 세포 생존율을 나타낸다고 보고되어 본 연구와 유사한 결과를 보여주었 다. 따라서 유산균 발효공정 적용 시 아사이베리의 항산화 활성이 증가함을 확인하였으며, 세포보호 효과 또한 나타 난 것으로 측정되었다.

\section{요 약}

본 연구에서는 다양한 생리활성을 가진다고 알려진 아 사이베리의 기능성 식품 소재로의 활용 가능성을 확인하 고자 유산균 발효 아사이베리 추출물을 제조하였으며, 이 화학적 품질 특성 및 생리활성을 조사하였다. 생균수는 발효 시간이 증가할수록 값이 증가하여 48시간에서 가장 높은 $7.38 \log \mathrm{CFU} / \mathrm{mL}$ 를 나타냈으며, $\mathrm{pH}$ 는 48 시간 배양 시 $\mathrm{pH} 4.30$ 으로 나타났으며, 산도는 48시간 배양 시 $0.54 \%$ 로 최대값을 나타내었다. 총당 함량은 배양시간이 증가할 수록 감소하여 0시간 배양 시 $51.50 \mathrm{~g} / 100 \mathrm{~g}$ 을 나타냈으며, 48 시간 배양 시 $41.86 \mathrm{~g} / 100 \mathrm{~g}$ 으로 최소값을 나타내었다. 총안토시아닌 함량은 배양시간이 증가할수록 값이 증가 하여 72시간 배양 시 $182.74 \mathrm{mg} / \mathrm{L}$ 로 최대값을 나타내었다. 총폴리페놀, 총플라보노이드 및 총프로안토시아니딘 함 량은 배양시간이 증가할수록 값이 증가하는 경향을 나타 내어 48 시간 배양 시 $34.74 \mathrm{~g} / 100 \mathrm{~g}, 25.88 \mathrm{~g} / 100 \mathrm{~g}$ 및 3.59 $\mathrm{g} / 100 \mathrm{~g}$ 으로 최대값을 나타내었다. DPPH 및 ABTS radical 소거활성은 $1,000 \mu \mathrm{g} / \mathrm{mL}$ 농도에서 48 시간 배양 시 $81.25 \%$ 및 $83.46 \%$ 로 최대값을 나타낸 후 감소하는 경향을 나타내 었으며, 이는 본 연구에서의 총폴리페놀 및 총플라보노이 드 함량 측정 결과와 유사한 경향을 나타냄을 확인하였다. FRAP 및 환원력의 흡광도 측정 결과, 48시간 배양 시 0.97 $\mu \mathrm{M}$ 및 1.10 으로 최대값을 나타내었다. 또한, 인간 폐상피 세포인 L132 세포에서 48시간 배양 시 $1,000 \mu \mathrm{g} / \mathrm{mL}$ 에서 세포보호 효과가 $89.60 \%$ 로 모든 시료 중 가장 높은 세포보 호 효과를 나타내었다. 따라서 유산균 발효 아사이베리 추출물은 48 시간 배양이 최적 발효 구간으로 판단되었으 며, 폴리페놀 및 안토시아닌 함량 등의 생리활성 물질 증 가로 기능성 식품 산업에서의 활용 가능성이 기대된다.

\section{감사의 글}

본 논문은 2019년도 대구가톨릭대학교 교내연구비 지 원에 의한 것으로 감사드립니다.

\section{Conflict of interests}

The authors declare no potential conflict of interest.

\section{ORCID}

Ji Wan Kim https://orcid.org/0000-0002-9680-8738

Joo-Heon Hong https://orcid.org/0000-0003-4360-3111

\section{References}

Benzie IFF, Strain JJ. The ferric reducing ability of plasma (FRAP) as a measure of "antioxidant power": The FRAP assay. Anal Biochem, 239, 70-76 (1996)

Blois MS. Antioxidant determinations by the use of a stable free radical. Nature, 1199-1200 (1958)

Cerpa-calderon FK, Kennedy JA. Berry integrity and extraction of skin and seed proanthocyanidins during red wine fermentation. J Agric Food Chem, 56, 9006-9014 (2008)

Chung HJ. Physiological activity of acai berry (Euterpe oleracea Mart.) extracted with different solvents. J Korean Soc Food Cult, 27, 75-81 (2012)

Davis WB. Determination of flavonones in citrus fruits. Anal Chem, 19, 476-478 (1947)

Dubois M, Gilles KA, Hamilton JK, Rebers PA, Smith F. Colorimetric method for determination of sugars and related substances. J Anal Chem, 28, 350-356 (1956)

Fine AM. Oligomeric proanthocyanidin complexes: History, structure, and phytopharmaceutical applications. Altern Med Rev, 5, 144-151 (2000)

Ha JH, Seo YC, Choi WY, Kim JS, Kim HH, Ahn JH, Lee HY. Enhancement of antioxidant activities of bark of Berberis Koreana palibin by lactic acid fermentation. Korean J Medicinal Crop Sci, 18, 421-428 (2010)

Hwang EG. Protective effects of $\alpha$-tocopherol and captopril against hydrogen peroxide-induced apoptosis on human lung epithelial cell line L-132. Ph D Thesis, Kyung Hee University, Korea, p 1-32 (2003)

Jeon BS, Park JW, Kim BK, Kim HK, Jung TS, Hahm JR, Kim DR, Cho YS, Cha JY. Fermented mushroom milk supplemented dietary fiber prevents the onset of obesity 
and hypertriglyceridemia in Otsuka Long-Evans Tokushima Fatty rats. Diabetes Obes Metab, 7, 709-715 (2005)

Jin DH, Lee YG, Seong JH, Kim HS. Comparison of bioactivities and antioxidant activities of acai berry (Euterpe oleracea Mart.) by different extraction solvents. J of Korean Oil Chemists Soc, 33, 741-750 (2016)

Jo HJ, Chung KH, Yoon JA, Song BC, An JH. Free radical-scavenging activities of amaranth (Amaranthus spp. L.) seed extracts. Food Eng Prog, 18, 116-123 (2014) Kang MS, Oh HJ, Lee HC, Oh JS. Isolation and identification of lactic acid bacteria inhibiting the proliferation of Propionibacterium acnes and Staphylococcus epidermidis. J Bacteriol Virol, 39, 11-19 (2009)

Kim GH, Bae EK. Lactic acid bacteria for the preservation of fruit and vegetables. Korean J Food Preserv, 6, 245-254 (1999)

Kim JH, Lee WJ, Cho YW, Kim KY. Storage-life and palatability extension of Betula platyphylla Sap using lactic acid bacteria fermentation. J Korean Soc Food Sci Nutr, 38, 787-794 (2009)

Kim MJ, Choi JH, Kwon SH, Kim HD, Bang MH, Yang SA. Characteristics of fermented dropwort extract and vinegar using fermented dropwort extract and its protective effects on oxidative damage in rat glioma C6 cells. Korean J Food Sci Technol, 45, 350-355 (2013)

Kim MJ, Shin NR, Lee MJ, Kim HJ. Microorganisms involved in natural fermentation of Asparagus cochinchinensis roots and changes in efficacies after fermentation. J Korean Med Obes Res, 18, 96-105 (2018)

Kim NY, Lee YD, Cho SC, Shin YC, Lee HY. Enhancement of anti-inflammation effect by fermentation process in Aronia melanocarpa (Michx.) elliot extract. Korean J Medicinal Crop Sci, 22, 475-482 (2014)

Kim SY. Physicochemical characteristics of acai berry (Euterpe oleracea Mart.) and acai berry wines. MS Thesis, Kyeong buk University, Korea, p 1-2 (2013)

Kong BM, Park MJ, Min JW, Kim HB, Kim SH, Kim SY, Yang DC. Physico-chemical characteristics of white, fermented and red ginseng extracts. J Ginseng Res, 32, 238-243 (2008)

Kwak CS, Choi HI. In vitro antioxidant and anti-inflammatory activities of ethanol extract and sequential fractions of flowers of Prunus persica in LPS-Stimulated RAW 264.7 macrophages. J Korean Soc Food Sci Nutr, 44, 1439-1449 (2015)

Lee DH, Hong JH. Physicochemical properties and storage stability of blueberry fermented by lactic acid bacteria. Korean J Food Preserv, 22, 796-803 (2015)

Lee HB, Kim HJ, Chong MS, Cho HE, Choi YH, Lim KS, Lee KN. Physiological activity of extracts from mixed culture of medical herbs and mycelia of Tricholoma matsutake and Cordyceps militaris by fermetation. Kor J Herbology, 23, 1-8 (2008)

Lee J, Dutst RW, Wrolstad RE. Determination of total monomeric anthocyanin pigment content of fruit juices, beverages, natural colorants, and wines by the $\mathrm{pH}$ differential method: Collaborative study. J AOAC Int, 88, 1269-1278 (2005)

Lee SM, You YH, Kim KM, Park JJ, Jeong CS, Jhon DY, Jun WJ. Antioxidant activities of native Gwangyang Rubus coreanus Miq. J Korean Soc Food Sci Nutr, 41, 327-332 (2012)

Lim MJ, Gu YR, Hong JH. Physicochemical properties and antioxidant activities of safflower (Carthamus tinctorius L.) extracts according to fermentation of lactic acid bacteria. J Chitin and Chitosan, 24, 24-32 (2019)

Michael H, Tasleem D, Ivan C. Acai (Euterpe oleracea Mart.) - A phytochemical and pharmacological assessment of the species health claims. Phytochem Lett, 4, 10-21 (2011)

Oyaizu M. Studies on products of browning reactionantioxidative activities of products of browning reaction prepared from glucosamine. Jap J Nutr, 44, 307-315 (1986)

Pacheco-palencia LA, Hawken P, Talcott ST. Phytochemical, antioxidant and pigment stability of acai (Euterpe oleracea Mart.) as affected by clarification, ascorbic acid fortification and storage. Food Res Int, 40, 620-628 (2007)

Park YS, Jang HG. Evaluation of lactic fermentation and biological activity of Rubus coreanus Miq. Appl Biol Chem, 46, 367-375 (2003)

Re R, Pellegrini N, Proteggente A, Pannala A, Yang M, Rice-Evans C. Antioxidant activity applying an improved ABTS radical cation decolorization assay. Free Radical Biol Med, 26, 1231-1237 (1999)

Schauss AG, Wu X, Prior RL, Ou B, Patel D, Huang D, Kababick JP. Phytochemical and nutrient composition of the freeze-dried amazonian palm berry, Euterpe oleraceae Mart. (Acai). J Agric Food Chem, 54, 8598-8603 (2006) Singleton VL, Rossi JA. Colorimetry of total phenolics with phosphomolybdic -phosphotungstic acid reagents. Am J 
Enol Viticult, 16, 144-158 (1965)

Song HK, Oh SJ. Isolation and structure elucidation of proanthocyanidin in bark of Pinus densiflora. J Kor Wood Sci Tech, 24, 81-93 (1996)

Sung HM, Lee YH, Jun WJ. In vitro hepatoprotective effects of fermented Curcuma longa L. by Aspergillus oryzae against alcohol-induced oxidative stress. J Korean Soc Food Sci Nutr, 45, 812-818 (2016)
Takahama U, Tanaka M, Hirota S. Proanthocyanidins in buckwheat flour can reduce salivary nitrite to nitric oxide in the stomach. Plant Foods Hum Nutr, 65, 1-7 (2010)

Van Meerloo J, Kaspers GJ, Cloos J. Cell sensitivity assays: The MTT assay. In Cancer Cell Culture: Methods and Protocols, Humana Press, New York, NY, USA, p 237-245, 731 (2011) 